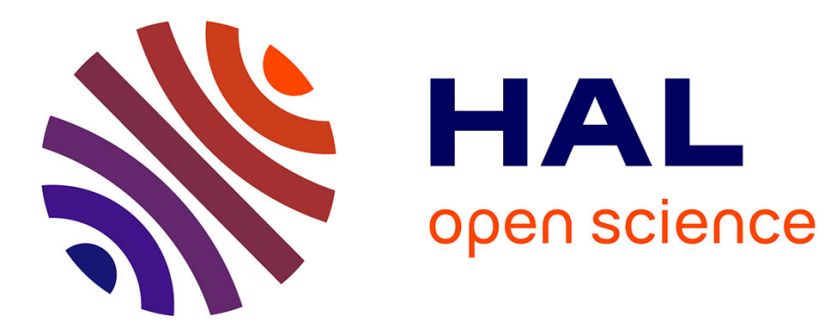

\title{
Echoing last words: Luis Camnitzer, Vanessa Place and critical dependency
}

\author{
Naomi Toth
}

\section{To cite this version:}

Naomi Toth. Echoing last words: Luis Camnitzer, Vanessa Place and critical dependency. Textual Practice, 2017, 33 (9), pp.1555-1576. 10.1080/0950236X.2018.1457564 . hal-03119703

\section{HAL Id: hal-03119703 \\ https://hal.parisnanterre.fr/hal-03119703}

Submitted on 25 Jan 2021

HAL is a multi-disciplinary open access archive for the deposit and dissemination of scientific research documents, whether they are published or not. The documents may come from teaching and research institutions in France or abroad, or from public or private research centers.
L'archive ouverte pluridisciplinaire HAL, est destinée au dépôt et à la diffusion de documents scientifiques de niveau recherche, publiés ou non, émanant des établissements d'enseignement et de recherche français ou étrangers, des laboratoires publics ou privés. 


\title{
Echoing last words: Luis Camnitzer, Vanessa Place and critical dependency
}

\author{
Naomi Toth \\ Faculty of Foreign Languages and Cultures, Université Paris Nanterre, Nanterre, France
}

\begin{abstract}
This article explores the political stakes of reprising the last statements of executed offenders as an artistic gesture. Last words represent a potential site of contestation of the sovereign power that is both reflected and constituted in the spectacle of capital punishment. Works of art reprising and recirculating these last words may, but do not necessarily, embody and amplify this disruptive potential. Jacques Derrida has suggested that claims of literary autonomy from the sovereign law in fact rely on the same logics of transcendence and idealisation that sustain the practice of the death penalty. This poses the problem of political commitment: is it possible to engage with the last words of the condemned without perpetuating the logics that underpin the spectacle of capital punishment itself? The figure of Echo, the mythical repeater of the last words of a sentence, might allow us to envisage a position of critical dependency: her repetitions neither transcend nor claim autonomy from the spectacle they partly reproduce, yet they differ from it nonetheless. The works of Luis Camnitzer (Last Words, 2008) and Vanessa Place (Last Words, 2015) are examined as examples of critical dependency's minimal potency.
\end{abstract}

ARTICLE HISTORY Received 13 December 2016; Accepted 26 July 2017

KEYWORDS Death penalty; political engagement; repetition; Echo; sovereignty; aesthetic autonomy; Luis Camnitzer; Vanessa Place; last words

\section{Show stoppers}

Michel Foucault opens Discipline and Punish with a now-famous analysis of Robert-François Damiens' torture and execution under the autocratic political regime of pre-revolutionary eighteenth-century France. ${ }^{1}$ In such spectacles, the confrontation between sovereign and subjects was inscribed upon the body of the condemned, to at least two ends. Firstly, to establish, or rather confirm, proof of the law's violation through the bodily reactions of the accused and the extraction of a confession; secondly, to re-establish, through the show's fascinating terror, the sovereign's wounded authority. That the people - the community of subjects - witness the event was therefore 
absolutely necessary for the show to go on. Prior to their execution, the condemned were given an opportunity to make a final statement. Although offenders' speeches could be used to petition the sovereign for clemency, they also often participated in the confession process, their words contributing to the authentication of the crime and thereby further validating the justice of the punishment.

Such a spectacle was, however, an unstable rite, and the condemned's last words, Foucault underlines, were one potential site of disruption. For their utterance could give the doomed subject a heroic allure, be it through acquiescence to the reality of the crime and acceptance of responsibility, in which case confession and remorse might lead to purification and paradoxical sanctification, or through defiance, which might transfigure the condemned into a rebel, gloriously resistant to the end. In both cases, the criminal becomes a sacrificial, if not martyr-like figure in the eyes of the people, from whose ranks he or she was inevitably drawn. Those attending an execution might, therefore, turn against the sovereign and side with the condemned. And indeed, throughout the eighteenth century, they increasingly did so, upsetting the scenography and challenging the regime of power the show quite literally embodied.

At the time, Foucault tells us, there flourished a literature of last words, of a more or less apocryphal nature. That such a literature was printed and circulated shows that it was, at the very least, tolerated by the authorities. Yet, as a relay of the spectacle of sovereign power that replayed both its infraction - its weakness - and its violence - its terror - this last words literature was a double-edged sword.

Foucault continues his argument in Discipline and Punish to trace subsequent shifts in the punitive paradigm, which include the progressive exclusion of bodily torture, the withdrawal of punishment from the public eye into the sphere of the secret, and the rise of the prison, all of which are concomitant with the fabrication of the subject of the modern state as an individual complete with a normatively regulated interiority, the reconstitution of the people as a mass of such individuals, and the generalisation of disciplinary practices of control. ${ }^{2}$ Our society, Foucault affirms in 1975, is no longer one of spectacle, but of surveillance. ${ }^{3}$ In such a context, he contends, last words literature has given way to other forms of crime writing, notably the detective novel, the thriller, and the fait divers. ${ }^{4}$

However, the death penalty has not disappeared. To consider its persistence as an anachronistic relic of an outdated regime of power, destined for extinction, would be both to subscribe to a questionable teleological view of history and to side-line the astonishing formal plasticity of the practice, which has kept pace with many of the other changes in disciplinary techniques, as shown by the uniformisation of its modalities, the omnipresence of discourses of risk, the restriction of immediate audiences to a minimum, 
and the concern to reduce bodily suffering, particularly visible bodily suffering, as far as possible. In the United States today, execution practices are not considered to contravene the eighth amendment of the Constitution prohibiting 'cruel or unusual' punishment.

To relegate the death penalty to the side-lines of power play would also be to ignore the role this practice continues to play in our contemporary imaginary of state power. As Jacques Derrida argues in his recently published seminar on the death penalty, ${ }^{5}$ capital punishment still functions as a symptomatic site of sovereignty. It exposes, as nowhere else, the nature of the state as the transcendent body that retains the right to arbitrate over the life and death of its subjects - and to exercise this right arbitrarily. Capital punishment is where the line is drawn between what we consider legitimate and illegitimate forms of violence, cruelty and killing; it is also where the possibility of pardon shimmers still, that is, where the possibility of making an exception remains constitutive of both of the rule and of sovereign rule more generally.

For capital punishment to function as such, it must be visible, Derrida argues. Indeed, where it continues, it continues as spectacle, be it of a very different nature to Damiens' public torture and death in eighteenth-century Paris. What attracts us to this now highly mediated show is not just the fascination of death per se, nor is the allure of crime and transgression alone responsible for our enthrallment. The event captivates because it is the moment at which the state might see the full extent of its power, at which it might see itself for what it is. As such, as an act of reflection, of presence to oneself, capital punishment continues to constitute the very identity of the state as sovereign. It follows that even in states where the death penalty has been abolished, now the majority, the questions the practice raises remain intact, as it traces the ideal horizon of sovereignty itself. ${ }^{6}$

A literature of last words also continues to circulate. In addition to numerous press articles citing the final statements of the condemned, the last decade has seen a number of art projects take up and redeploy their words. ${ }^{7}$ What are we to make of this resurgence of a literature and an art reprising the last words of executed offenders where representative democracy, not autocracy, is the name of the game - that is, where audience and sovereign are no longer imagined as discrete, distinct entities that confront each another? ${ }^{8}$ What relationship do such artistic projects establish with the spectacle they partly reproduce? In other words, what form of engagement do they propose?

To address such questions, two scenes must be considered. Firstly, the scene upon which the last words are uttered. This scene is, in fact, double, for it is constituted by repetition in and of itself. Secondly, the scene upon which the statements are recirculated as an artistic gesture. Two aesthetic projects are of particular interest here: Last Words, a series of six wall panels produced by the visual artist Luis Camnitzer $(2008)^{9}$ and the artist book Last Words by the poet and performance artist Vanessa Place (2015). The figure 
of Echo, the famous repeater of the last words of a sentence, the nymph who followed Narcissus fascinated by his own reflection, becomes a useful tool to analyse each work's position in relation to the spectacle of power and identity it reproduces and the nature of the artistic engagement proposed.

\section{Spectacle/s}

The source material for both Luis Camnitzer and Vanessa Place's projects is the Texas Department of Criminal Justice website, ${ }^{10}$ and for good reason: not only is the state of Texas emblematic, as it carries out the lion's share of executions in the USA, the major Western democracy that continues to practice the death penalty, ${ }^{11}$ but it also makes the last statements of executed offenders publically available in an online archive. In Texas, the spectacle of capital punishment unfolds in two stages, on two stages.

Firstly, there is the execution itself. This event, circumscribed in time and space, has a highly restricted but gradually growing immediate audience: representatives of the media and up to five people selected from the offender's visitor list have always been allowed to attend; since 1996, members of the victim(s)' family may also be present; since 1998, close friends and extended family of the victim(s), and, since 2008, their spiritual advisors. ${ }^{12}$ These spectators watch from an observation room separated from the execution chamber by bay windows. The offender is strapped to a gurney, arms outstretched in a form which resembles a crucifix. This sacrificial iconography, so prevalent in capital punishment over history, only further underlines the economies of debt and retribution that underpin the death penalty, ${ }^{13}$ while also evoking one of its guiding principles: that of a transcendent life beyond this one, the greater life of the law, in whose name an individual organic life, that of the prisoner, might be given up. ${ }^{14}$ The prisoner is then given the opportunity to make a last statement, captured by a microphone suspended from the ceiling and transmitted simultaneously to the observation room and another one in which the words are transcribed. When the speaking ceases, the execution begins.

The condemned speak only once, but not for all - at least, not yet. The transcription of their last statement is then published on the Texas Department of Criminal Justice website, the show's second platform. These last words make up the final element on the offender's public file, which also includes his or her name, birth date, race, hair and eye colour, level of education, county of origin and of conviction, details of the crime for which he or she was convicted, date of admission to death row, and a mug shot. When added to the dossier, often after a significant delay, these words are made available to a global audience, accessible at any time and in any place the internet extends to, to whomever so desires, as many times as they desire. And a lot of us do: in 2013, the New York Times reported that the website receives 3 million hits annually. ${ }^{15}$ 
In this spectacle, the last words no longer perform many of the functions Foucault identifies in eighteenth-century France's town square executions. The condemned cannot hope to use this occasion to plead for exceptional grace, as such appeals take place prior to the execution. The final statement no longer contributes to proving the nature of the crime committed, nor does it further confirm the guilt of the subject, the facts of the matter having already been established during public trial in court. The ends served lie elsewhere. No longer proof of crime, last words now act as proof of punishment: they are the sole supplement that distinguishes the 'scheduled execution' dossier from the 'executed offender' dossier on the state's website. They thereby testify to death itself, acting as a receipt for a penalty paid, balancing the scales unevenly weighed down by the description of the crime committed which features on that same website. They also serve to prove that the condemned is aware of what is happening. Indeed, the prisoner's conscious participation is not only solicited, it is required for retribution to be effective. Refusal to speak is considered sufficient to establish consciousness of the coming event's gravity, and is also recorded. In this sense, last words function as a signature, one which might not signify assent - although many last words do express the speaker's agreement with the procedure - but at the very least intelligent presence, awareness of what is about to occur. Without them, punishment would not be properly punishment, and our satisfaction diminished.

Like a signature, last words are thought to show singularity: along with the mug shot, they are the only marks of idiosyncrasy in the whole spectacle, the only signs that differentiate this particular death from so many others like it. Last words thus sign off not only on the imminent execution but also on the individual life that is about to end. Their performance may therefore be analysed in relation to the literary genre of Famous Last Words more generally. What assures the celebrity of last words retained in this tradition is their ability to capture something perceived as essential either about the occasion or the speaker, who is usually, but not always, famous. ${ }^{16}$ That is, Famous Last Words respond to the imperatives of narrative, defining either a character or an event in a plot, often both. In our cultural imagination, they carry a truth revealed on the brink, one that will retrospectively illuminate and accord meaning to the scattered and haphazard events that precede it. ${ }^{17}$ That a number of the Texas death row prisoners quote other famous last words in their own last statement only reinforces the literary status of their performance. ${ }^{18}$ And when we recall that the authority for moral instruction to be drawn from a person's story in the oral folk tradition depends on the manner of their passing, their death retroactively giving their life a particular shape, at least if we follow Walter Benjamin's analyses in 'The Story-Teller', it becomes even clearer that a last statement is the opportunity for the prisoner to weigh in on their own denouement and on the lesson to be drawn from their own life story in the retelling. ${ }^{19}$ 
Confessions of guilt, requests for absolution, claims of innocence and affirmations of defiance are recurring themes in these last words. ${ }^{20}$ As such, they continue to exploit their potential to produce ambivalent moral sanctification or subversive glorification. The state's reproduction of the only language produced from the position of the subject as the conscious object of the sovereign act of ultimate power thus remains equivocal, both affirming and shoring up the spectacle on the one hand, while simultaneously representing a potential point of friction, a site at which the state's best intentions might yet go awry.

\section{Compromising autonomy}

The second scene is the gallery, where not the state, but artists and poets, take up and reproduce these last words. Here, Derrida's discussion of literature's status in relation to the death penalty must be considered. Derrida hypothesises that the historically extraordinary situation in which we find ourselves, in which debate over the death penalty has led to its abolition in a majority of states worldwide, may be linked to the institution of literature in the narrow, modern sense of the term. The two phenomena are indeed contemporary. Modern literature's emergence as a separate discipline, as a way of using of language that differs from philosophy and other forms of knowledge, is usually dated back to the eighteenth century, Kant's categorical distinction between truth and beauty only confirming a separation that was already well underway. ${ }^{21}$ This distinction coincides with the rise of the figure of the individual author as a creative genius and the conception of art as personal expression. Literature henceforth makes a claim for a certain autonomy. This assertion of independence is made not only in relation to other disciplines but also to the power regime in place. For the institution of literature is contemporary with the emergence of the modern, democratic state as the locus of sovereign power. Indeed, as Derrida has argued elsewhere, literature comes into being as such 'before the law' of the modern state. ${ }^{22}$ It is dependent on this law, which determines its rights and prerogatives, yet it is also sufficiently different from the law to interrogate it. Likewise, the law is dependent on literary structures, in spite of its own claims of autonomy, that is, of absolute distinction from regimes of language that call upon narrative. Literature and the law of the modern state are thus inextricably bound up, and their relationship of co-creation is characterised by constant attempts to distinguish one sphere from the other.

The death penalty plays a role in this face-off between literature and the law. Derrida argues that the relationship between discourses of literary autonomy and the death penalty is double-sided. On the one hand, an autonomous literary sphere is presupposed by writers who plead for the death penalty's abolition. Literature here claims to be separate from the law of the land and therefore in touch with a more fundamental natural law whose reign 
extends beyond the specific configurations of a given justice system. Authors, claiming the authority that comes with independence, seek to wield this natural law as an alternative to the sovereign's law requiring death. This is the humanist side of the Enlightenment, and its heritage is abolitionist: Derrida cites Victor Hugo and Albert Camus as emblematic of this position. And yet, goes Derrida's argument, their abolitionism participates in the same transcendent logic that supports capital punishment and sovereignty itself. Where Hugo's argument explicitly involves the deferral of the decision on the life or death of a human being to a higher power, God, Camus' apparently atheist argument relies upon a natural right to life that transcends the limits of human justice and thereby bears, beyond surface differences, a structural similarity to Hugo's more overtly theological abolitionism. ${ }^{23}$

On the other hand, literature's autonomy is imagined as deriving from language's power to sentence its object to death, to destroy organic, individual lives, to abolish any private, interior, unspoken life, and to do so in the name of another form of life, one that is entirely public and visible, one that exists only in language, in literary language. And so Maurice Blanchot, in his essay 'La Littérature et le droit à la mort ${ }^{24}$ sees in the Revolutionary moment of the Terror and the guillotine the genesis of literary autonomy: this, for Derrida, is the Sadian flip-side of the Enlightenment coin, and its legacy, carried through into the twentieth century via Mallarmé and the Symbolists, is crucial to the rise of a transcendent, quasi-sacred approach to literature itself, one that gained so much currency amongst critics in France in the early and mid-twentieth century. Literature's eternal life, in this logic, is a paradoxical life beyond death; its absolute liberty is founded upon the writer's capacity to use language to suppress both its subject (the speaker) and its object (the spoken), creating an inorganic, public and transcendent life that surpasses the material one. Thus Blanchot contends that Robespierre comes to exist as a character the moment his head fell from the guillotine. That is, that his literary being could only come to be, and come to be eternally, when liberated from the constraints of his actual existence. ${ }^{25}$

In both of these versions of aesthetic autonomy, Derrida argues, literature claims to exceed the law of the land with which it is nonetheless bound up; in both cases, the same logic of sacralisation, of deferral to a transcendent life beyond the material lives of individual humans is deployed, either to oppose, as Hugo and Camus do, the death penalty, or to find in the death penalty its fascinating foundation, as Blanchot or Jean Genet do. In other words, any assertion of autonomy from the sovereign authority administering capital punishment necessarily implies a position in relation to that power, one that, sometimes covertly, supports or, often overtly, contests the death penalty, but, in both cases, one that adheres to the same logics of transcendent power and idealisation that underpin the structure of sovereignty itself. 
This then begs the question: what, if any, is art's difference from the mechanisms of the spectacle it takes up and partially repeats? What kind of autonomy is claimed, and what position is, openly or implicitly, adopted towards it? Is it possible to create art from this material without participating in the very processes of idealisation and transcendence that legitimate the spectacle itself?

\section{Echo or repetition as critical dependency}

Perhaps. This is where the figure of Echo becomes a useful critical tool. For if we are to take seriously Derrida's contention that sovereignty sees itself in the terrible mirror of capital punishment, then this spectacle functions as a privileged site in the constitution of our contemporary Narcissus: it engages us as spectators of ourselves. Our subjectivities are constructed by vastly different techniques of power and discipline to those that determined the audience attending public tortures in the town square in pre-Revolutionary France. Sovereign and subject are no longer incarnated in separate bodies, on the contrary: the ideology of the representative democratic state intertwines both sovereign and subject in the figure of the self-regulating citizen. Contemporary spectators of the death penalty participate, in theory at least, in the law's construction, validation and implementation, and witness, in an execution, the moment where the extremes of sovereign power and subjection meet. We stand, captivated by the sombre flash that reveals ourselves as offender and warden, fascinated by the almighty power there reflected. This show exposes our part in the sovereign authority that both constitutes and transcends the state, the law, ourselves.

If the death penalty is our reflecting pool, the identity we construct there is what Echo comes after. Echo, however, is a figure endowed neither with sovereignty nor authority. In Ovid's Metamorphosis, Juno ensures that 'when speaking ends, all [the nymph Echo] can do is double each last word / And echo back the voice she's heard'. ${ }^{26}$ Authorship, along with individual creative expression, is thus denied her: she is a-literary, in the modern sense of the term 'literature' outlined above. Her ontological status is problematic: unlike most other figures in the Metamorphosis she has no genealogy, that is, no origin, and her transformation leaves no tangible trace in the form of a plant or an animal, only an invisible auditory phenomenon. ${ }^{27}$ Deprived of complete life, she is also incapable of proper death: indeed, after her debacle with Narcissus, her body wastes away in grief but her voice continues, resounding in the interstice between life and death, an opposition she seems to simultaneously straddle and ignore.

And yet, though her voice provides no content, the most cursory glance her dialogue with Narcissus in Ovid's text shows that Echo's repetitions cannot to be understood in terms of simple imitation: 


\begin{tabular}{lc}
\hline Narcissus & Echo \\
\hline Anyone here? & Here! \\
Come this way! & This way! \\
Why run away? & Run away? \\
Here, let us meet together! & Together! \\
\hline
\end{tabular}

At this point, Echo appears and tries to throw her arms around him but Narcissus rejects her:

\begin{tabular}{lc}
\hline Narcissus & Echo \\
\hline $\begin{array}{ll}\text { Keep your arms from me! Be off! } \\
\text { I'll die before I yield to you. }\end{array}$ & I yield to you. ${ }^{28}$ \\
\hline
\end{tabular}

The meaning intended and the meaning echoed back are discomfortingly different: Echo has Narcissus' own words serve other, opposing, desires. Turning partiality to her advantage, repetition in her mouth becomes subversion, transformation and active response. It is not surprising then that John Hollander, in his seminal study of the figure of Echo in Western literature, reminds us that Ovid's Echo is linked with satire, ${ }^{29}$ a genre which ironically reflects back to society its own unacknowledged truths.

That repetition of verbal display might expose things an initial utterance hides encourages us to read Echo's reprisals in the light of Gilles Deleuze's Difference and Repetition (1968), ${ }^{30}$ where he distinguishes between two approaches to repetition. The first concerns repetition of an original understood as already identical to itself. Repetition in this schema is something less than the real thing; it is understood primarily in terms of diminishment or loss. Such a conception of repetition is consistent with an understanding of representation as imitation and with metaphysical dualism, in which first comes Idea, then come its lesser, more or less corrupt replicas. ${ }^{31}$

Rather than opposing this model to another, Deleuze identifies the problem it attempts to resolve and outlines its terms. This enables him to develop a second approach to repetition as dissymmetry, in which difference is an affirmative entity in and of itself, propelling the very movement of thought. Here, difference precedes identity which proceeds from it, emerging as identity from the shifting, plural foundations of non-identical return. Identity that parades as originality is therefore only ever the fictive product of the movement of repetition: it can only take on the appearance of an original essence by erasing the difference that produced it. In other words, the price to be paid for identity as originality, for identity as Ideal, is the exclusion of difference in all its a-conceptuality, movement and bettise - its stupidity and animality. Repetition as imitation therefore both relies on and covers over the movement of repetition as dissymmetry. Seemingly solid and supposedly original identities are sealed over another world of proliferating differences and repetitions. Repetition understood as the reproduction of a Master - in 
the case at hand, a Master spectacle, which is, moreover, a spectacle of mastery - sweeps these differences under the carpet of the institutions of justice or the gallery.

The repetition that constructs the visibility of state sovereignty within the spectacle of capital punishment in Texas may be understood in terms of this first kind of repetition: the Department of Criminal Justice website repeats last words in order to reinstate a certain, wounded ideal of justice, to secure an ideal of sovereignty and subjectivity, to reaffirm the identities necessary for the functioning of the modern state. This is repetition that participates in the construction of an ideal of state power, one that we, as subjects and sovereigns, each embody. Echo's repetitions, on the other hand, refuse to pay the price exacted by such reasonable, ordered representation and its attendant identities. Rather than reinforcing the spectacle of sovereignty, her performance plumbs its fissures, forcing a way into that which has been swept off scene, thereby undermining the very ideals the first type of repetition is there to guarantee. Without, however, laying claim to an autonomous realm from which to stake a position relative to the spectacle reproduced. The works of Luis Camnitzer and Vanessa Place, which recirculate only the words of the spectacle itself, may be understood in these terms. ${ }^{32}$

Luis Camnitzer's Last Words is made up of six panels upon which are printed an edited selection of the last words sourced from the Texas Department of Criminal Justice website. The text is printed in pigment on paper, using serif font. Serif is the typeface of administrative documents, and pigment is the print mode preferred by archives, as it is reputed for its longevity and ensures perfect identical reproduction on a mass scale. Luis Camnitzer thereby inscribes his work in the tradition of administrative records that the source website perpetuates. However, the text is printed in a single block with no distinction between different entries, a gesture that thwarts any attempt to retrieve specific information about a given execution and thus undermines its archival function. The text is arranged as a book chapter: there are 38 lines of text printed on each sheet, which corresponds to the standard length of a book page; the first page begins a third from the top and the text on the final page does not reach the bottom; and page numbers appear centred at the bottom of each sheet. The scale of each panel is not, however, that of a book: at around five and a half by four feet each, ${ }^{33}$ they reach the height of an average adult when hung on gallery walls (Figure 1). The viewer very soon realises that the selection criteria for the sentences reproduced is the presence of the word 'love' in the last statements. ${ }^{34}$ This word comes back as a refrain as one reads the texts, appearing on almost every line (Figures $2-4$ ).

There is no selection in the on-going project conducted by Vanessa Place, an American criminal lawyer, poet, and performance artist who records her own voice reading aloud all the last words of the executed, every one of 


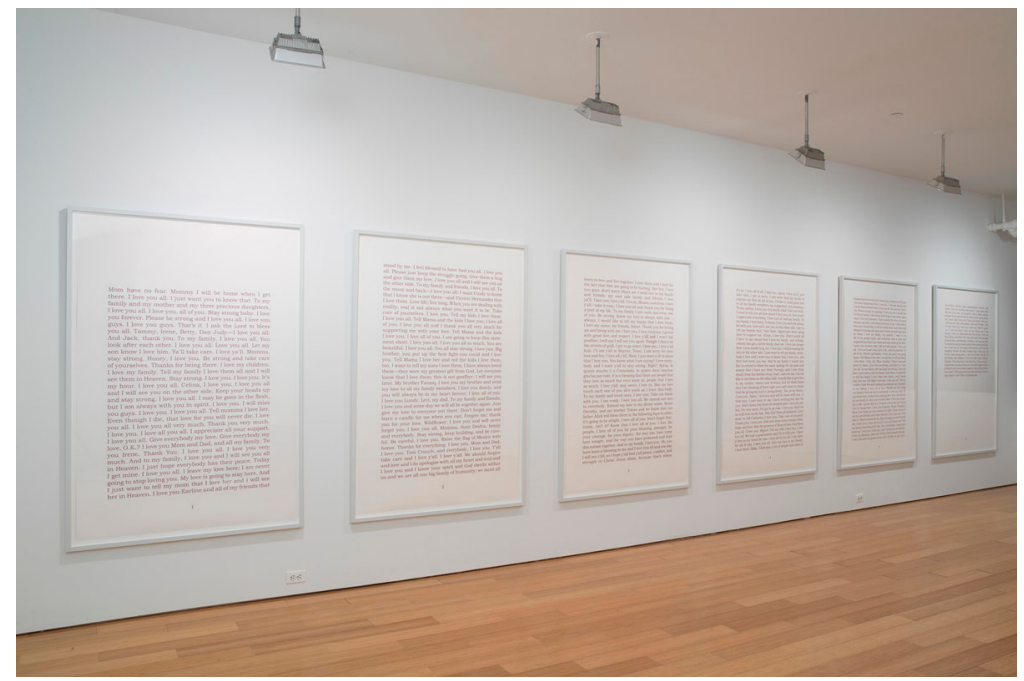

Figure 1. Luis Camnitzer, Last Words, 2008, Installation view, Alexander Gray Associates (2008), Pigment prints in 6 parts, $66 \mathrm{~h} \times 44 \mathrm{w}$ in $(167.64 \mathrm{~h} \times 111.76 \mathrm{w} \mathrm{cm})$, Edition of 3 with 1 AP, Courtesy Alexander Gray Associates, New York, ( 2017 Luis Camnitzer/Artists Rights Society (ARS), New York

them, marking refusals to speak by five seconds of silence. Though she renews the recordings regularly, not all of them appear in her artist book published by Dis Voir in 2015 and entitled Last Words. The book comprises an introductory text citing extracts from 11 last statements and printed in the form of a poetic preface. On each of the following 60 pages, 6 mug shots of prisoners are aligned from left to right, forming a vertically centred band of 360 photos in all. Inside the book cover is a CD of Vanessa Place's own voice reading aloud as many last words as will fit on a single $\mathrm{CD}$ (one hour and 15 minutes). The last statement read corresponds to the most recent record uploaded on the Department of Criminal Justice website at the time of the recording, that of Manuel Vasquez, executed on 11 March 2015, and the number of last words included on this particular recording were calculated retroactively. Though the recording proceeds by chronological order of execution, this does not, however, allow for a neat match between the words pronounced and the mug shots in the book, as Manual Vasquez's image does not appear on these pages.

Luis Camnitzer and Vanessa Place's works both repeat the spectacle of capital punishment partially. What they omit shapes our reading of the material in numerous ways. Most obviously, by choosing exclusively the words of the condemned and not those of the state, both artists adopt the position of the one the spectacle suppresses: the guilty, the heinous, the one we would eliminate in order to ensure our own power and our own innocence. ${ }^{35}$ 
Mom have no fear. Mommy I will be home when I get there. I love you all. I just want you to know that. To my family and my mother and my three precious daughters, I love you all. I love you, all of you. Stay strong baby. I love you forever. Please be strong and I love you all. I love you guys. I love you guys. That's it. I ask the Lord to bless you all. Tammy, Irene, Betty, Dan Judy-I love you all. And Jack, thank you. To my family, I love you all. You look after each other. I love you all. Love you all. Let my son know I love him. Ya'll take care. I love ya'll. Momma, stay strong. Honey, I love you. Be strong and take care of yourselves. Thanks for being there. I love my children. I love my family. Tell my family I love them all and I will see them in Heaven. Stay strong. I love you. I love you. It's my hour. I love you all. Celina, I love you. I love you all and I will see you on the other side. Keep your heads up and stay strong. I love you all. I may be gone in the flesh, but I am always with you in spirit. I love you. I will miss you guys. I love you. I love you all. Tell momma I love her. Even though I die, that love for you will never die. I love you all. I love you all very much. Thank you very much. I love you. I love all you all. I appreciate all your support. I love you all. Give everybody my love. Give everybody my love, O.K.? I love you Mom and Dad, and all my family. To you Irene, Thank You. I love you all. I love you very much. And to my family, I love you and I will see you all in Heaven. I just hope everybody has their peace. Today I get mine. I love you all. I leave my love here; I am never going to stop loving you. My love is going to stay here. And I just want to tell my mom that I love her and I will see her in Heaven. I love you Earline and all of my friends that

Figure 2. Luis Camnitzer, Last Words, 2008, detail, Pigment prints in 6 parts, $66 \mathrm{~h} \times 44 \mathrm{w}$ in $(167.64 \mathrm{~h} \times 111.76 \mathrm{w} \mathrm{cm})$, Edition of 3 with 1 AP, Courtesy Alexander Gray Associates, New York, @ 2017 Luis Camnitzer/Artists Rights Society (ARS), New York

This gesture also withdraws the last words from the narrative of retributive justice constructed by the state's website, such that the text here no longer functions as proof of punishment for a specific crime that might restore balance to the scales of justice. The spectator/listener is instead invited to consider the statements and the deaths in and of themselves. This opens the words and the event up to other narrative configurations. Presenting the words as a book chapter, as Louis Camnitzer does, or enfolded in the cover 
stood by me. I feel blessed to have had you all. I love you all. Please just keep the struggle going. Give them a hug and give them my love. I love you all and I will see you on the other side. To my family and friends, I love you all. To the moon and back-I love you all. I want Cindy to know that I know she is out there-and Vicente Hernandez that I love them. Love life; live long. When you are dealing with reality, real is not always what you want it to be. Take care of yourselves. I love you. Tell my kids I love them. I love you all. Tell Mama and the kids I love you; I love all of you. I love you all and I thank you all very much for supporting me with your love. Tell Mama and the kids I love you; I love all of you. I am going to keep this statement short. I love you all. I love you all so much. You are beautiful. I love you all. You all stay strong. I love you. Big brother, you put up the best fight you could and I love you. Tell Mama I love her and tell the kids I love them, too. I want to tell my sons I love them; I have always loved them-they were my greatest gift from God. Let everyone know that I love them; this is not goodbye. I will see you later. My brother Farooq, I love you my brother and send my love to all my family members. I love you dearly, and you will always be in my heart forever. I love all of you. I love you Lundy, Levi, my dad. To my family and friends, I love you and some day we will all be together again. Just give my love to everyone out there. Don't forget me and burn a candle for me when you can. Forgive me; thank you for your love. Wildflower: I love you and will never forget you. I love you all, Momma, Aunt Deidra, family and everybody. Stay strong, keep building, and be careful. Be careful. I love you. Raise the flag of Mexico with honor. Thanks for everything. I love you. Mom and Dad, I love you. Tom Crouch, and everybody, I love you. Y'all take care and I love y'all. I love y'all. We should forgive and love and I do apologize with all my heart and soul and I love you and I know your spirit and God dwells within us and we are all one big family of humanity; we must all

Figure 3. Luis Camnitzer, Last Words, 2008, detail, Pigment prints in 6 parts, $66 \mathrm{~h} \times 44 \mathrm{w}$ in $(167.64 \mathrm{~h} \times 111.76 \mathrm{w} \mathrm{cm})$, Edition of 3 with 1 AP, Courtesy Alexander Gray Associates, New York, @ 2017 Luis Camnitzer/Artists Rights Society (ARS), New York

of an artist book, as Vanessa Place does, gestures towards the narrative nature of the law on the one hand, and on the other hand, makes the plurality of other possible narratives the event might participate in, palpable.

The materiality of the voice and the body of the condemned are other aspects the state spectacle suppresses but these two projects draw to our attention. Vanessa Place's recording reintroduces voice, that enigmatic indicator of breath so often associated with life and the illusion of presence in our Western phonocentric tradition. ${ }^{36}$ And yet, the expression animating the words clearly does not come from the self that generated them, but from another. As in the 
Echo myth, the voice of Vanessa Place differs in obvious ways from the voice that initially pronounced the words heard in the state spectacle, and nothing is done is to reduce the gap between the two. No attempt is made to imitate affect, timbre or tone. The voice in the recording is feminine, evenly modulated, and the same throughout, smoothing over any differences between statements made mostly by males. It has a televisual quality which accentuates the public nature of the scene in which the textual material was produced. If this is poetry, 'voice' here has little to do either with the individual expression of the poet, or with the survival of an original speaker. Any individual personality remains irretrievable, doubly buried in this distanced re-vocalisation that conjures up life's breath in such a way as to underscore its absence. Though voice is restored, presence is denied, and loss goes unassuaged.

The organic, corporal nature of the condemned is obliquely indicated in Luis Camnitzer's work. Firstly, his choice of material, pigment on paper that is, cellulose - suggests that in this spectacle, skin is being laid on the line. Though no explicit racial markers exist on Camnitzer's panels, the disproportionately high numbers of non-white offenders executed in the United States is made visual in Vanessa Place's artist book, where the aligned mug shots stuck one after the other encourage the viewer to take in the photos in one block. Distinctions therefore emerge on a collective scale, and the very high proportion of people of colour amongst the executed becomes all the more obvious. The question of race, critical in capital punishment debates in the United States, ${ }^{37}$ is thus raised without comment.

Luis Camnitzer's work also calls up the body by choosing to use pigment of a reddish-brown colour, reminiscent of dried blood. This draws attention to something developments in capital punishment techniques have progressively done away with, something contemporary audiences find intolerable: the sight of blood. Sanguinary displays of suffering are indeed now considered worse than death itself. Lethal injection, the means of killing in Texas, performs its task in the veins, such that spectators' eyes are spared by the screen of skin. Camnitzer's choice of colour may therefore be read as an attempt to de-anesthetise the viewer by rendering the medium through which death is administered visible. The sacrificial nature of the event is also brought to the surface: the blood shed for the shoring up of the law is here absorbed into the typeface of the law itself. These annals of humankind are written in letters of blood, which the artist invites us to drink with our eyes in turn. The colour is not the gush of the red, vital, blood of the living, rather it is of the dry, browned and deadened variety, stripped of any gore and its attendant fascination. This may dull its attraction and foreclose titillation, but it does not attenuate the spectator's ambivalence when faced with the work.

This ambivalence is compounded by another way Camnitzer's work evokes the body of the executed offender. The size of the panels obliges the viewer's gaze to move up and down each one from head to toe, appraising them as if 
my mother, brother, sister, grandmother, cousins, and nieces, and my brothers and sisters I have never met. My love to my son, my daughter, Nancy, Kathy, Randy, and my future grandchildren. Sister Doris, mom, brothers, sister, dad; I love ya'll. Chris and David, I love you. I love you all. Stay strong Mary, take care of them. I love you too. I love you, I love you. I am sorry. That's it, goodbye. I love you Irene, I love you sis. Thank you to my family, I love you. Each and every one of you. I love you dad, Devin, and Walt. Yes, Love you mom, love you pop, love you Sara, and Amanda. Jermaine, I love you too man. To my family and my mother and my three precious daughters, I love you all. I love you, I love my son, and I love my daughter. Bruno, Chuckie, Juanita, Ray-I love you, all of you. Stay strong baby. I love you forever. Yes sir, to my family and children, I love you very much. Dianne, Virginia, Toby and Irene I love all of you. I love you guys. I appreciate you all and love you. You all brought me here to be executed, not to make a speech. I have no last words. I am ready. Tell the guys on Death Row that I'm not wearing a diaper. I can't think of anything else.

Figure 4. Luis Camnitzer, Last Words, 2008, detail, Pigment prints in 6 parts, $66 \mathrm{~h} \times 44 \mathrm{w}$ in $(167.64 \mathrm{~h} \times 111.76 \mathrm{w} \mathrm{cm})$, Edition of 3 with 1 AP, Courtesy Alexander Gray Associates, New York, (c) 2017 Luis Camnitzer/Artists Rights Society (ARS), New York

each were a body. We are thereby invited to identify with the corporality of the condemned while simultaneously performing scanning gestures analogue to those of the doctor looking for the vein in order to administer the fatal dose. Or again, we might be adopting the position of the warden supervising the scene.

The enigmatic closing line of the text on the final panel (Figure 4) - 'I can't think of anything else' - could, syntactically, refer to the diaper mentioned in 
the previous sentence: 'Tell the guys on death row I'm not wearing a diaper.' This further underscores the organic nature of the body on the gurney and the materiality of death itself. That the moment of death is explicitly identified with the expulsion of physical excrement only highlights the value given to the body that is to be ejected from our society so that the state body, the ideal sovereign body - our bodies - might be cleansed, in a scatological variation on the sacrificial theme. Who is expulsing what thereby becomes the question the viewer cannot avoid. Luis Camnitzer seems to defy the viewer to experience the work as catharsis, showing up the stakes of such a desire for a purifying purge, making the price of aesthetic pleasure explicit.

The 'anything else' that cannot be thought has, however, no easily identifiable, fixed reference. It may, of course, refer to that unimaginable event that is one's own death, imminent for the speaker. Or to the fact that the speaker, like the reader, may not be able to think of anything else but the love repeated ad nauseum on the preceding panels. Indeed, the role of affect in the spectacle is another feature Luis Camnitzer brings to the fore, for the viewer's greater discomfort. Some have understood the selection of text based on the presence of the word 'love' as bringing a 'glimmer of humanity' to the work. ${ }^{38}$ And it is undeniable that this evocation of 'love' might appeal to the viewer's pity, a feeling that could easily be enlisted to serve humanist arguments for abolition. However, as Patrick Greaney has pointed out, when considered along with the other forms of minimal participation Camnitzer's composition requires, the situation becomes more complicated. Firstly, the depersonalisation of the statements problematises the nature of the address they imply. On the one hand, the 'Mom' that opens the text on the first panel operates a distinction between the addressee and the viewer, while simultaneously situating the discourse in the realm of the intimate. This places the viewer in the position of the voyeur, which again raises the question of the pleasure experienced when reading these affirmations of love. As in Vanessa Place's piece, this viewer/listener-voyeur also occupies a position comparable to that of the warden who hears the words in the first instance. On the other hand, as the sentences continue in an undifferentiated block, the singularity of the addressee is gradually effaced and the difference between viewer of the art work and the initial addressee of the words wavers. Greaney also highlights the indeterminacy of the speaker the work creates: the condemned capital criminal who initially pronounced the words, the staff who record them, and the artist who represents them are all possible sources of the utterance, all potential fillers of the deictic 'I'. It follows that this 'love' addressed to 'you', the viewer, might provoke feelings of rejection or repulsion as much as anything else. ${ }^{39}$

This discomfort only increases when we consider these words in the context of the sacrificial motif that traverses the history of the death penalty, one version of which is the idea that the condemned dies in someone else's stead, precisely because he or she loves the one that gets off. 
The most famous model of such sacrificial love is of course, Christ's death to satisfy divine law which was thereby vindicated and the world's guilt absolved. That more than a few executed offenders cite Christ's last words is not therefore surprising. ${ }^{40}$ The 'love' Camnitzer's work foregrounds may therefore ring strangely in our ears, rendering any affective satisfaction highly ambivalent. It might not comfort the viewer at all, but have quite the opposite effect. Such expressions of 'love' therefore may undermine as much as they may support abolitionist indignation, while simultaneously preventing any advancement in the 'healing processes' the spectacle of execution might seem to promise to death penalty advocates. ${ }^{41}$

While the convocation of the suppressed body and voice in Camnitzer and Place's work might seem to use iteration in an incantatory manner so as to set the scene for the spectral return of those the spectacle represses, repetition here is neither redemption nor raising of the dead. ${ }^{42}$ There is no attempt to rehabilitate the condemned: both artistic projects resist the temptation to reincarnate the criminal, to resuscitate lost bodies or reproduce lost voices. ${ }^{43}$ Camintzer's condensing of multiple last words in one seamless text prevents any individual body from emerging, and the repetition of 'love' only undercuts the singularity and specificity of any given declaration. Likewise, the uniformisation Vanessa Place's voice imposes prevents us from hearing an identifiable voice speaking from beyond the grave. On the contrary, refrains emerge in her recording as the words accumulate. Internal repetitions slowly organise themselves into categories in the listener's ears. As he or she begins, almost involuntarily, to classify the statements, a typology emerges: apart from expressions of love, other themes include confession, expression of remorse, acceptance of the event about to happen, protestation against the death penalty, affirmation of innocence, and religious prayers. Vanessa Place's voice tells us that even at the brink, originality fails, and it tells us this again and again. Both projects therefore disappoint any hope that last words might 'sum up' a subjective narrative identity, and refuse to allow any moral to be drawn from the dead man or woman's story. The artists' gesture is no more than a deadening repetition of the sign of death, re-enacting the law's accomplishment, in all the polysemy of that term. No character, neither saint nor villain, is brought into linguistic existence through art, and repetition, here, does not make anything better.

It follows, then, that though their works differ in important ways from the spectacle they partially reproduce, they do not construct a literary or aesthetic space that might claim autonomy from the scene they repeat, one that might allow for an abolitionist or anti-abolitionist position to be identified. The two artists have both publically argued that it is impossible to step outside state ideology, to acquire an autonomy in which expression might be personal and genius original. ${ }^{44}$ Vanessa Place describes her work as being 'afterideology' - 'after' as in a copy that does not situate itself outside the ideological 
artefacts it reproduces, but rather exploits what she describes as the infrathin' difference that makes poetry poetry ${ }^{45}$; Luis Camnitzer has argued that the only choice left to the artist, unable to genuinely free him- or herself from the determinations of the society in which he or she is situated, is that of 'bearing critical witness' ${ }^{46}$ These positions are not, however, my principal argument here: the formal strategies both artists deploy amply demonstrate that their art cannot attain a more fundamental, natural or theological realm external to the sovereign law, nor generate an inorganic, linguistic eternal life beyond it, one that might, through the elevation of language into art, redeem the executed and ensure a glorious - or tantalisingly inglorious - life beyond death. Instead, like Echo, these works inhabit a liminal space that is dependent on sovereign law, while being at the same time not the law. A space that makes no claim to aesthetic autonomy, but that might be described as critical dependency.

What is more, as the audience of this reprised spectacle we are again cast as participants, but set at just enough distance from the first spectacle for us to catch a fleeting glimpse of that which it suppresses, of the differences it seeks to expulse so as to better shore up our sovereignty, to better ensure our righteous identity. Echoing last words, then, does not offer a way out, but it might be the only way to bore into the spectacle of capital punishment without perpetuating its idealising logic. Though to what ends, we cannot say: Echo loves Narcissus, and chooses to follow him; her voice is not Narcissus', but depends entirely on his words. Therein lies the problem, our problem: in such conditions of amorous dependency, neither Echo nor the critic can have the last word. And so the show goes on.

\section{Notes}

1. Michel Foucault, Surveiller et punir. Naissance de la prison (Paris: Gallimard, 1975); Discipline and Punish: The Birth of the Prison, trans. Alan Sheridan (London: Allen Lane, 1977; New York: Random House, 1979). All page references here are made to the French text.

2. Ibid., pp. 154-55.

3. Ibid., pp. 252.

4. See ibid., pp. 82-3; 334-5.

5. Jacques Derrida, Séminaire. La Peine de mort (Paris: Galilée, 2012); The Death Penalty. Volume I, trans. Peggy Kamuf (Chicago: University of Chicago Press, 2013). All page references are made to the French text.

6. See Derrida, op. cit. especially the third seminar, as well as the seminar summaries (EHESS seminar and the Irvine spring seminar) reprinted in the introduction, pp. 15-7.

7. In addition to the two works discussed here, see the following projects, all of which draw on the same source, the Texas Department of Criminal Justice website: 'Goodbye Warden' (goodbyewarden.com); Andy Smith's 'Lasting Statements' (lastingstatement.com); Darius Kazemi work Last words, in 
which he flashes a selection of sentences taken from the last statements which include the word 'love' in white on a black background (http://tinysubversions. com/stuff/lastwords/); Amy Elkin's 2014 photography work Parting Words, which won the Aperture prize (images available here: http://www.amyelkins. com/parting-words). One of several articles on her work appeared in the Huffington Post, Nick Wing, 'Texas has Executed So Many Inmates There is Now Art Made Entirely Out of their Last Words' (29 May 2014, web). This article also commented on the online success of a word cloud generated from the Texas State Department of Criminal Justice's material, available at http:// imgur.com/t61UIgH. The French poet and video artist Frank Smith's 2016 video work Fin de mots, based on a translated and edited selection of 16 last words from this archive, is now available online: https://vimeo.com/179557596.

8. The exercise of the death penalty under other political regimes goes well beyond the scope of this article. The four countries that carried out the greatest number of executions in 2015 - China, Iran, Pakistan, and Saudi Arabia - all fall into this category. See Amnesty International, Death Penalty 2015 Facts and Figures, (web. 6 April 2016: https://www.amnesty.org/en/latest/news/2016/04/ death-penalty-2015-facts-and-figures/).

9. The work may be seen online on the Alexander Gray Associates Gallery website here: http://www.alexandergray.com/artists/luis-camnitzer/luis-camnitzer_3/

10. https://www.tdcj.state.tx.us/death_row/dr_executed_offenders.html

11. In Amnesty International's rankings, the United States holds the 5th place in terms of numbers of executions carried out per year.

12. 'Victim Services Division', Texas State Department of Criminal Justice website, https://www.tdcj.state.tx.us/divisions/vs/victim_viewing_executions.html, consulted 13 November 2016.

13. See Friedrich Nietzsche, On the Geneology of Morals, ed. Robert C. Holb, trans. Michael A. Scarpetti (London: Penguin Classics, 2013), second and third dissertations. See also Jacques Derrida's commentary on Nietszche in the sixth session of the seminar on the Death Penalty, op. cit. p. 216 onwards.

14. See Derrida, op. cit., especially p. 32 and the commentary of Kant, introduced pp. 180-5.

15. Manny Fernandez, 'From America's Busiest Death Chamber: A Catalog of Last Rants, Pleas, and Apologies', New York Times, June 30, 2013, web.

16. See Gary Saul Morson's chapter dedicated to this genre in The Words of Others: Quotations to Culture (New Haven, CT and London: Yale University Press, 2011).

17. Literary examples abound: Kurtz's famous last words in Conrad's Heart of Darkness, described as a 'summing up' of his life, is but one of the more well known. Joseph Conrad, Heart of Darkness and Other Tales, ed. Cedric Watts (Oxford: Oxford World Classics, 2008), p. 179.

18. Two examples of many: David Ray Harris, executed on 30 June 2004: 'Yes I do. Sir, in honor of a true American hero, "let's roll”. Lord Jesus receive my spirit.' 'Let's roll' is a quotation of the last words of Todd Beamer, passenger on United flight 93, before charging the cockpit of one of the high-jacked planes that was to participate in the terrorist attacks on American on 11 September 2001. References to Christ's last words are also frequent: amongst many others, Allen Janecka, executed on 24 July 2003: '[...] Lord, into your hands I commit my spirit'. 
19. Walter Benjamin, 'Der Erzhäler', (1936) translated as 'Le Narrateur', Écrits français, ed. Jean-Maurice Monnoyer (Paris: Gallimard, 1991); the essay appears in English in, amongst many other editions, Dorothy J. Hale (ed.), The Novel: An Anthology of Criticism and Theory 1900-2000 (Malden, MA: Blackwell Publishing, 2006). See in particular the end of section X and the beginning of section XI.

20. See the various typologies of last words referred to in Robert Jonson, Laura Caitlin Kanewske and Maya Black, 'Death Row Confinement and the Meaning of Last Words', Laws, 3 (February 2014), pp. 141-52, pp. 142-4.

21. See, on this subject, amongst a vast bibliography, Pierre Macherey, $\grave{A}$ quoi pense la littérature? (Paris: Presses Universitaires de France, 1990), in particular the introduction; Camille Dumoulié, Littérature et philosophie: Le Gai savoir de la littérature (Paris: Armand Colin, 2002).

22. See, on this point, Derrida's essay 'Before the Law', translated by Avitai Ronell and Christine Raulson, published in Jacques Derrida, Acts of literature, ed. David Attridge (New York and London: Routledge, 1992), pp. 181-220. See also 'Préjugés, devant la loi', a different version of the same essay published in Jacques Derrida, Vincent Descombes, Garbis Kortian, Philippe LacoueLabarthe, Jean-François Lyotard, Jean-Luc Nancy, La Faculté de juger (Paris: Minuit, 1985), pp. 87-139.

23. Derrida, op. cit., 10th and 11th seminar sessions, in particular p. 378.

24. First published in Critique in 1948, and reprinted in Maurice Blanchot, La Part du feu (Paris: Gallimard, 1949).

25. Derrida, op. cit., pp. 164-75.

26. Ovid, Metamorphoses, trans. A. D. Melville (Oxford [1986], 2008), p. 62.

27. Cf. Véronique Gély, La Nostalgie du moi: Écho dans la littérature européenne (Paris: Presses Universitaires de France, 2000), p. 29.

28. This restitution of the dialogue is based on two translations: the afore-cited translation by A. D. Melville, and that of A.S. Kline (University of Virginia Library Digital Production Group, 2000).

29. John Hollander, The Figure of Echo (Berkeley and Los Angeles: University of California Press, 1981), p. 15.

30. Différence et répétition (Paris: Presses Universitaires de France, 1968); Difference and Repetition, trans. Paul Patton (New York: University of Columbia Press, 1994). All subsequent references are made to the French edition.

31. Deleuze identifies the four attributes of classical representation as (1) the identity of the concept to itself; (2) its opposition to the predicate, (3) judgement as analogical and (4) perception as resemblance. Ibid., p. 337 onwards.

32. Vanessa Place has likened her own practice to that of Echo. See the interview After Vanessa Place, by Vanessa Place and Naomi Toth, London: Ma Bibliothèque, 2017, especially pp. 55-84.

33. Alexander Gray Associates, http://www.alexandergray.com/artists/luiscamnitzer/luis-camnitzer_3/ consulted 13 November 2016.

34. Ibid.

35. On the construction of guilt and innocence in the American legal system, see Vanessa Place, The Guilt Project: Rape, Morality and the Law (New York: Other Press, 2010).

36. See, amongst others, Jacques Derrida, La Voix et le phénomène (Paris: Presses Universitaires de France, 1967). 
37. See the racial statistics concerning the death penalty in the USA since 1976, published by the Death Penalty Information Centre: 'National Statistics on the Death Penalty and Race' (consulted 17 November 2016, web). http:// www.deathpenaltyinfo.org/race-death-row-inmates-executed-1976\#Vic. This question is also a major one in debates around the death penalty in the United States, as crystalised by and in the now-famous text by Mumia AbuJamal, Live from Death Row (Reading, MA: Addison-Wesley, 1995).

38. Manny Fernandez, art. cit.

39. Patrick Greaney, 'Last words: Expression and Quotation in the Work of Luis Camnitzer', The Germanic Review 98 (2014), pp. 89-120, p. 119.

40. Cf. note 18 above.

41. See the 'Victim Services Division' page, Texas Department of Criminal Justice website.

42. In this sense, repetition operates differently from that identified by J. Hillis Miller in Fiction and Repetition (Cambridge, MA: Harvard University Press, 1982), notably in his reading of repetition in the work of Virginia Woolf as 'the raising of the dead'. The mode of repetition discussed here could however complement J. Hillis Miller's explorations of the phenomena in nineteenth and twentieth century English language fiction, which he reads as a largely generative practice.

43. A comparison with another contemporary work reprising last words may be useful here. Amy Elkin's photographic project Parting Words (2014) takes up to three sentences from each last statement recorded on the Texas State Department of Criminal Justice website, which are then repeated line after line, in ink of various shades of grey so as to reconstruct the mug-shot of the executed offender, also taken from the website. The repetition of these last words thereby conjures up the image of the dead, giving the text an incantatory quality. Each image has for its title the executed offender's name, date of execution and age. When exhibited along walls in the form of square panels that resemble memorials erected in memory of victims of mass tragedies or to contemporary crematorium plaques, this work appears as a commemorative homage to those killed, creating a form of afterlife for them, if not a kind of linguistic rehabilitation. This project therefore stakes out a position in relation to the spectacle it repeats, albeit an ambivalent one. On one level, like Camnitzer and Place, Elkin withdraws of the last words from the narrative of the state's website, presenting the criminal in the exclusive position of the victim of violence and not of its perpetration. Combined with the sacralisation of the identities of the executed and the memorial aspect of her work, this gesture could be read to serve the arguments that oppose the death penalty, potentially provoking indignation, suggesting that killing human beings, whatever their past may have been, is unacceptable. And yet, at another level, this work plays into our fascination with the criminal, creating a hall of infamous characters, not dissimilar from Blanchot's Robespierre and other figures of the Terror. Pete Brooks has written that Elkin 'turns the logic of a flawed system against itself (in 'Parting Words: The Visual Story of Death Row Prisoner's Last Words' Huffington Post [February 6th, 2014, web]), however it seems that, on the contrary, her project draws upon the very transcendent logics that legitimate the system itself. Its interest lies in the fact that the viewer is not given directions as to which of the two sides to take. 
44. They both fall into the category of what Marjorie Perloff has called 'unoriginal genii'. Unoriginal Genius: Poetry by Other Means in the New Century (Chicago: University of Chicago Press, 2010).

45. See in particular Vanessa Place and Robert Fitterman, Notes on Conceptualisms, Vanessa Place and Robert Fitterman, Notes on Conceptualisms (New York: Ugly Duckling Presse, 2009), p. 20, and Vanessa Place, 'After Ideology', paper delivered at the international conference L'Expérience de la contingence historique dans les arts et la littérature (1914-2014), organised by Hélène Aji and Charlotte Estrade, Université Paris Ouest Nanterre, 6 November 2014. Text available at: http://www.academia.edu/11711721/After_Ideology

46. Luis Camnitzer, On Art, Artist, Latin America and Other Utopias, ed. Rachel Weiss (Austin: University of Texas Press, 2009), especially ch. 19: 'Revisiting tautology' [originally published in 2006], pp. 159-63), p. 162. His interest in the paradoxes of utopia also support this: for Camnizter, any utopia art might provide can only ever be glimpsed as the concrete the display of any artwork's power-based, ideological underpinnings, of art's corrupt imperfection. See, in particular, 'The Two Versions of Santa Anna's Leg and the Ethics of Public Art' (1995), ibid., ch. 24, pp. 204-5. See also Patrick Greaney, art. cit. 